\title{
A Discriminant Analysis of Insurance Companies in Ukraine
}

\author{
Viktoriia Riashchenko
}

Doctor of Economics, Professor, ISMA University, Latvia.

Viktoriia Kremen

$\mathrm{PhD}$, Associate Professor, Sumy State University, Ukraine.

\section{Tetiana Bochkarova}

Master Student, Sumy State University, Ukraine.

\begin{abstract}
Determining and forecasting the financial situation of insurance companies of Ukraine has become an important issue of financial supervision in view of the need to ensure the sustainability of the financial sector and reduce the negative impact of the insolvency of insurance companies. Given the significant number of bankruptcies of insurance companies in Ukraine in recent years, a discriminatory method may be applied to improve off-site financial supervision. The paper analyzes the advantages and disadvantages of discriminatory models developed for companies producing goods and providing non-financial services to banking institutions and insurance companies. It is substantiated that in order to improve the quality of estimation and forecasting of the financial state of insurance companies in Ukraine, the development of a discriminant model should take into account the domestic specificity of the insurance business. The scientific work defines the stages of development and testing of the quality of a discriminant model for determining the financial status of insurance companies in Ukraine. For the development of a discriminant model, taking into account the existing statistical base, 31 indicators of activity of 12 insurance companies for 2015 were selected. The selection of statistical indicators for use as factors in a discriminant model was performed on the basis of a two-choice F-test, a Farrar-Globard algorithm, a matrix of pair coefficients of correlation. A discriminatory model for determining the financial status of insurance companies in Ukraine included net returns on equity, asset turnover ratios, insurance risk rates, and changes in equity. The application of the model allows you to determine whether the insurance company has a satisfactory or unsatisfactory financial condition. Approval of the developed discriminant model has proven its high quality.
\end{abstract}

Keywords: insurance company, financial status, discriminatory analysis, discriminatory function.

JEL Classification: C15, C35, G22, G33, M21.

(C) The Authors, 2017. This article is published with open access at ARMG Publishing.

\section{Introduction}

At the current stage of development of the Ukrainian economy, all types of financial intermediaries have to constantly face crisis phenomena, which are aggravated in conditions of military aggression, devaluation of the national currency, distrust of state power, high level of corruption, low investment attractiveness and significant debt burden. Negative macroeconomic processes in the economy directly affect the state of the insurance sector. In particular, the National Commission, which carries out state regulation in the field of financial services markets, in 2016 revoked licenses and excluded from the State Register of Financial Institutions information about 41 insurance companies, and also revoked the licenses of another 8 insurers. The grounds for suspension of the license were violations of the provisions of regulatory acts, as well as nonfulfillment of licensing conditions. Also, the liquidation process in insurance may be pushed by the fact that the TOP 50 life insurance companies and TOR 100 insurance companies cover about $100 \%$ of gross premiums (Report of the National Commission that performs state regulation in the field of financial services markets), that is, only about 150 companies out of 361 actually operate, others are pocket money. The bankruptcy of banks in recent years also indirectly affected the activities of insurers: the funds necessary to ensure the solvency of the market, placed, in particular, on deposits in banks and are not covered by guarantees. Negative influence was the increase of tariffs for reinsurance of risks for Ukraine as for territory with high probability of insurance events. Also, the problem for insurers is a ban on transferring foreign currency payments introduced by the National Bank of Ukraine, which creates the inability to reinsure risks in foreign markets and the potential increased loss-making or failure to pay out a chain of insurance events. In world practice, the use of discriminatory analysis tools based on the empirical study of the financial performance of a wide range of effectively operating companies and companies liquidated through bankruptcy is quite common. It is necessary to have a comprehensive assessment of the financial position of the company in terms of the 
probability of bankruptcy, which can be carried out with the help of multi-factor discriminant analysis tools (Iankovets, 2016).The discriminant function derived by means of mathematical statistics and economicmathematical modeling enables one to calculate an integral indicator for a particular company, which provides an opportunity to determine the future financial state and predict the probability of bankruptcy. In addition to uniqueness of the results, the advantages of multi-factor discriminant analysis, include: ease of use, availability of necessary information, high reliability of the assessment.

\section{Literature review}

In the context of research, the noted problem has certain theoretical pre-conditions. In particular, aspects of discriminant analyses of companies were reflected in works of foreign as well as national researchers.

The largest number of discriminant models is developed for companies producing goods and non-financial services. One of the most common approaches to a generalizing assessment of the financial state is the coefficient of W. H. Beaver's method.

The methodological approach is based on the calculation of five coefficients: W. H. Beaver's indicator, return on assets, financial leverage, coverage of assets by net working capital and coverage (Conan,1979). The advantages of this approach include the simplicity of calculations and the optimal, small, number of factors, but the approach is characterized by a long forecast period and failure to take into account the industry specificity of enterprises. The developed J.Conan and M. Holder model is based on the calculation of five financial indicators, belonging to profitability groups, cost coverage and financial sustainability (Conan,1979). It should be noted that the use of this model is somewhat complicated, since it requires the formation of a broad statistical base. Also, it does not take into account the specifics of the activities of the companies.

At the same time, the approach of these scholars to assessing the promising financial position of the company can reveal long-term problems and assess financial constraints for three years ahead. The Lisa R. Gilbert model, developed for companies in England, reflects the level of threat to the company's autonomy. The use of the model is simple, because it is based on four indicators that reflect the efficiency of the use of assets, which determine the company's ability to repay its debts. Model R. J. Taffler, H. Tisshaw predicts the calculation of four indicators, among which the largest weight $-53 \%$ - has a ratio of income from sales to current liabilities. This model is easy to calculate, has a high accuracy of $97 \%$ for the 1 year forecasting horizon, but does not take into account the market value of business and is not suitable for a modern information base of settlements. Model D.L. Chesser allows predicting the potential financial insolvency of a potential borrower. Moreover, the model provides for the possibility of forecasting not only the risks of non-repayment of the loan, but also any other deviations that make the loan unprofitable for the creditor. Also, the advantage of this model is the ability to conduct an express diagnosis of the financial condition of the company or assess its creditworthiness.

At the same time, it should be noted that the model is based on a limited number of factors and a focus on credit ratings as the ultimate goal of the company's research. Developed by Gordon L.V. Springate model is based on the following performance indicators: the share of current assets in assets, the ratio of net cash flow and assets, the ratio between operating income and short-term liabilities, and the turnover of assets. The advantages of the model include the high accuracy of the forecast. However, the model is developed for companies in the US and Canada, and is also a modification of the well-known model E.I. Altman, which somewhat reduces its analytical capabilities.

The JG Fulmer model takes into account a large number of factors: the ratio of retained earnings over the years and assets, asset turnover, operating profitability of equity, cash flow ratio and long-term liabilities, share of long-term liabilities and assets, share of short-term liabilities and assets, the volume of tangible assets, the ratio of current assets and long and short-term liabilities, the ratio of net cash flow and interest paid. The accuracy of the forecast of the financial condition of the company, determined by this model, for the 1year horizon is $98 \%$, for the 2-year-old - $81 \%$ (Fulmer, 1984).

The advantage of the model is also to take into account the size of the company. At the same time, it should be borne in mind that the model is specifically designed to meet the information needs of banks when working with corporate clients. Among the Ukrainian discriminatory models developed for companies in the real sector of the economy, O. Tereshchenko's model is most well-known. The model includes seven financial and economic indicators that belong to the groups of profitability, business activity, cash flow and capital 
structure [20]. It is difficult to use and insufficiently high level of accuracy. In addition, the model assumes a fairly large uncertainty interval for predicted estimates. At the same time, the developed model takes into account the specific features of the activity and can be used for the companies of the mining, metallurgical industry and energy complex. No financial intermediaries in general, nor for insurance companies, the use of the model is not provided. To date, there are significant developments regarding the use of discriminatory analysis to predict the bankruptcy of banking institutions. D. Martin developed a group of equations for early warning of bankruptcy of banks in 1969-1974. For each of these years, he determined the number of bankbanks and banks that continued their activities, on the basis of which he put forward the null hypothesis that each bank has the same propensity to bankruptcy, which is equal to the ratio between bankrupt and bankrupt banks in the corresponding year. In his study, he investigated the impact on the banks of 25 factors that were grouped as follows: asset risk, liquidity, capital adequacy, income. D. Martin constructed a logit-regression equation for different horizons of forecasting. J. Hanequ's research is based on a sample of 177 banks whose activities were evaluated in 1973-1975. The probit regression eventually included the following factors: net operating profit / total assets; equity / total assets; \% change in net operating profit / total assets; $\%$ change in total assets; loans / capital; the size of the bank in terms of assets. R. Barr and T. Sims proposed in 1996, together with factors of direct banking activity - equity / loans, inactive credits / assets, net income / assets, large deposits / assets - factors such as quality of management and economic conditions. The models were constructed for one-year and two-year horizons of forecasting, the accuracy of which is estimated at 92.4 and 94.8\% (Richard, 1996). One of the most well-known is the multi-factor bankruptcy forecasting model of the bank by Canadian scientist Y.Kocak who, for its development, investigated the influence of 87 factor indicators on the financial condition of the bank. The accuracy of the estimation using this model is $95.7 \%$. Scientists M. Halling and E. Hayden on the basis of reporting 1100 Austrian banks have developed a basic logit model, as well as expanded models to take into account the bank's operating period. In addition, the authors proposed to improve the model by taking into account the transition of banks to the "at risk" situation, which the authors consider in several aspects (Halling, 2008).

In 2013, Ukrainian scientists AV Kherep and OA Komissarenko received a discriminatory function-an indicator of the forecasting of bankruptcy of banks. Of the 24 factors that were considered for inclusion in the function, only five were left in the study: profitability of assets, the ratio of operating expenses and operating income, the ratio of loans and liabilities, return on capital, the ratio of deposits and liabilities (Cherep, 2013).

Despite the rather non-widespread use of methodical tools for discriminatory analysis in insurance, there are still deciles in this direction. Scientists from Romania, C. Anghelache and D. Armeanu, applied a discriminant analysis for the classification of insurance companies operating in the Romanian insurance market in 2006. Based on the results of the study, 8 indicators were selected: gross written premium, net mathematical reserves, gross claims paid, net premium reserves, net claims, net income, share capital and gross written premiums ceded in reinsurance (Anghelache, 2008). In the work of Z. D. Martínez, J. F. Menéndez and J. S. Vargas, nonparametric methods were used to predict the financial condition of insurance companies along with discriminant analysis. These methodological approaches have been used for non-life insurance companies in Spain (Martinez, 2004). The construction of a discriminant model requires a certain prehistory, expressed in the statistics of the operation of insurance companies. The application of a discriminant model developed for insurance companies in one country may lead to erroneous forecasts of the financial condition of insurance companies in another country. Taking into account the non-adaptation of foreign discriminatory models to the conditions of Ukraine and the specifics of the functioning of the domestic financial sector and the insurance market, the purpose of the article is to develop a discriminant model for determining and forecasting the financial condition of insurance companies in Ukraine.

\section{Methodology}

The development of a discriminant model for insurance companies in Ukraine is proposed to be carried out according to the algorithm presented in Figure 1. 
1. Selection of liquidated and stable insurance companies

2. Formation of an array of data for use in the process of constructing a model

3. Selection and calculation of indicators for which the financial condition of the insurance company will be assessed

4. Verification of the significance of the factors selected for the model using the two-sampled F-test for dispersions

5. Evaluation of the relationship between the selected indicators (checking the presence of multicollinearity between the variables using the Farrar-Globard algorithm and by constructing a matrix of pairwise correlation coefficients)

6. Construction of the equation of discriminant function, checking its adequacy and reliability

7. Application of the obtained discriminant model for forecasting the financial condition of insurance companies and checking its adequacy

Fig. 1. Algorithm for constructing a model for insolvency analysis of insurance companies

Source: compiled by the authors.

At the first stage, we chose liquidated and stable insurance companies based on the data of the National Commission, which carries out state regulation in the field of financial services markets. The number of insurers that are financially stable and the number of liquidated insurance companies were the same. 12 insurance companies were selected for the research, of which 6 insurance companies were liquidated (PJSC IC "Vector Invest", PJSC IC "Vector Invest Life", PJSC SC "Standard Re”, PJSC SC “Zlagoda”, PJSC SC "Atlanta", PJSC USC "Garant-Life") and 6 are financially stable (PJSC NASK "Oranta", PJSC SC "Providna", PJSC SG “TAS”, PJSC “UPSK”, PJSC USC “Knyazha”, PJSC IC “Unika”). In the second stage, based on the financial statements of insurance companies for 2015, we have formed an array of indicators that are reflected in the statement of financial position and income and expenditure of fear Closed companies. In the third stage, for each of the selected insurance companies, we calculated 31 indicators. At the same time, these indicators relate to different groups - liquidity, solvency and financial stability, profitability, business activity, as well as specific indicators of the insurance company's early warning insecurity tests (Table 1). In the fourth stage, we tested the significance of the factors selected for the model with the help of a two-sample F-test for dispersions. The results are shown in Table 2. Given the levels of freedom with a probability of 0.95 , the table value of the F-criterion is 0.198 . Comparing the calculated values with the critical one, we excluded the following from the set of indicators due to their statistical insignificance: $X_{1}, X_{2}, X_{3}, X_{4}, X_{5}, X_{9}$, $X_{10}, X_{12}, X_{13}, X_{14}, X_{15}, X_{16}, X_{17}, X_{18}, X_{21}, X_{22}, X_{24}, X_{26}, X_{28}, X_{29}, X_{30}, X_{31}$.

At the fifth stage, we evaluated the relationship between the selected indicators. The verification of multicollinearity between variables was performed using the Farrar-Globard algorithm and by constructing a matrix of pair correlation coefficients. In the framework of the Farrara-Globard algorithm, we implemented the standardization of variables, formed a correlation matrix. Then, having determined the criterion $\chi^{2}$, we have come to the conclusion that there is multicollinearity in the data array, after all $\chi^{2}>\chi^{2}(134,66>23,27)$.

By constructing a matrix of pair correlation coefficients (Table 3), we have identified factors that strongly depend on each other and exclude them. It has been proved that there are such factors as: $X_{6}$ and $X_{7} ; X_{6}$ Ta $X_{25} ; X_{7}$ та $X_{25} ; X_{8}$ та $X_{20} ; X_{11}$ has a close connection with $X_{19}, X_{20}, X_{23} ; X_{19}$ has a close connection with $X_{20}$ та $X_{23} ; X_{20}$ has a close connection with $X_{23}$.

In order to get rid of multicollinearity, we decided to exclude the following factors: $X_{6}, X_{8}, X_{11}, X_{20}, X_{25}$. 3 taking into account the previously excluded factors, we obtain a new list of indicators for constructing a discriminant model: $X_{1}$ (net return on equity), $X_{2}$ (коефіцієнт обігу активів), $X_{3}$, (insurance risk indicator) and $X_{4}$ (rate of change in capital).

At the next, sixth stage, we computed the standardized coefficients and constructed a discriminant function that got the following form (1): 
$Z=\sum_{i=1}^{n}\left(a_{i} \times X_{i}\right)=a_{1} \times X_{1}+a_{2} \times X_{2}+a_{3} \times X_{3}+a_{4} \times X_{4}$,

Where $a_{i}-\mathrm{a}$ coefficient that characterizes the change in the integral value of a function when the corresponding factor factor per unit; $X_{i}$ - the value of the corresponding factor indicator.

To calculate the standardized coefficients, we constructed two matrices of independent variables in which the number of columns was equal to the number of model variables, and the number of rows was the magnitude of the sample population, and the average values of each of the indices of both groups were calculated and two vector-lines were calculated. After that, we found the vector of the difference between the mean values of the independent variables for the two groups (Table 4). At the next stage, we constructed two covariance matrices of values of independent variables for the first $\left(W_{l}\right)$ and second $\left(W_{2}\right)$ groups of insurance companies and the average covariance matrix is determined $W$, each element of which is an arithmetic mean of the corresponding matrix elements $W_{l}$ i $W_{2}$ :

$$
W=\left|\begin{array}{cccc}
0.46 & -0.02 & -0.32 & 0.32 \\
-0.02 & 0.76 & 1.76 & -1.23 \\
-0.32 & 1.67 & 4.24 & 0.56 \\
0.32 & 0.36 & 0.56 & 0.94
\end{array}\right|
$$

Table 1. Indicators of the activities of insurance companies that were considered from the point of view of inclusion in a discriminatory model

\begin{tabular}{|c|c|c|}
\hline № & Indicator & Method of calculation \\
\hline$X_{I}$ & Total liquidity ratio & Working capital / (Short-term liabilities + Insurance reserves) \\
\hline$X_{2}$ & Urgent liquidity ratio & $($ Cash + Short-term financial investments $) /$ Short-term liabilities \\
\hline$X_{3}$ & Current liquidity ratio & $\begin{array}{l}\text { (Working Capital - Long-term Accounts Receivable) / (Short-term Accounts Payable } \\
+ \text { Insurance Reserves) }\end{array}$ \\
\hline$X_{4}$ & Critical liquidity ratio & $\begin{array}{l}\text { (Cash }+ \text { Short-term financial investments }+ \text { Short-term receivables) } / \text { (Short-term } \\
\text { payables }+ \text { Insurance reserves) }\end{array}$ \\
\hline$X_{5}$ & Absolute liquidity ratio & Cash / Short-term liabilities \\
\hline$X_{6}$ & Total return on equity & Amount of balance profit / Volume of capital \\
\hline$X_{7}$ & Net Return on Own Capital & Net profit / Equity \\
\hline$X_{8}$ & Profitability of invested capital & $\begin{array}{l}\text { Income from investing in insurance reserves / (Short-term financial investments }+ \\
\text { Long-term financial investments }+ \text { Securities) }\end{array}$ \\
\hline$X_{9}$ & Absolute liquidity ratio & Most liquid assets / Short-term liabilities \\
\hline$X_{10}$ & Current liquidity ratio & (Current assets - Expenses of future periods) / Short-term liabilities \\
\hline$X_{11}$ & Asset turnover & Income of the insurance company / Assets \\
\hline$X_{12}$ & Turnover of equity capital & Total Revenues / Equity \\
\hline$X_{13}$ & Turnover of current assets & Total Revenues / Current Assets \\
\hline$X_{14}$ & The coefficient of autonomy & Equity / Capital \\
\hline$X_{15}$ & $\begin{array}{l}\text { The coefficient of financial } \\
\text { dependence }\end{array}$ & Capital / Equity \\
\hline$X_{16}$ & $\begin{array}{l}\text { The coefficient of capital's } \\
\text { maneuverability }\end{array}$ & (Current assets - Current liabilities) / Equity \\
\hline$X_{17}$ & The coefficient of financial stability & Equity / Debt capital \\
\hline$X_{18}$ & The concentration of debt capital & Loan Capital / Capital \\
\hline$X_{19}$ & Asset turnover ratio & Net Income / Assets \\
\hline$X_{20}$ & Rate of return on equity & Net income / Equity \\
\hline$X_{21}$ & Indicator of receivables & Accounts Receivable / Capital \\
\hline$X_{22}$ & Asset liquidity index & Highly liquid assets / Liabilities \\
\hline$X_{23}$ & Indicator of insurance risk & Net Awards / Capital \\
\hline$X_{24}$ & Reversal of solvency & Commitment / Capital \\
\hline
\end{tabular}


Table 1. (cont.). Indicators of the activities of insurance companies that were considered from the point of view of inclusion in a discriminatory model

\begin{tabular}{|l|l|l|}
\hline$X_{25}$ & Rate of return & Net profit / Capital \\
\hline$X_{26}$ & Index of volumes of underwriting & Payments and expenses / Net earned bonuses \\
\hline$X_{27}$ & Chart of capital changes & Capital at the end of the period / Capital at the beginning of the period \\
\hline$X_{28}$ & $\begin{array}{l}\text { Indicator of changes in the amount of } \\
\text { net bonuses for all policies }\end{array}$ & $\begin{array}{l}\text { Amount of net premium at the end of the period / Amount of net premiums at the } \\
\text { beginning of the period }\end{array}$ \\
\hline$X_{29}$ & $\begin{array}{l}\text { Indicator of independence of } \\
\text { reinsurance }\end{array}$ & Net amount of bonuses / Gross amount of bonuses \\
\hline$X_{30}$ & $\begin{array}{l}\text { Indicator of the ratio of reserves to } \\
\text { capital }\end{array}$ & Net insurance reserves / Capital \\
\hline$X_{31}$ & Return on investment & Profit from financial activities / Financial investments \\
\hline
\end{tabular}

Source: compiled by the authors.

Table 2. Value of F-criterion for insurance companies

\begin{tabular}{|c|c|c|c|c|c|c|c|}
\hline Indicator & $X_{1}$ & $X_{2}$ & $X_{3}$ & $X_{4}$ & $X_{5}$ & $X_{6}$ & $X_{7}$ \\
\hline$F$-standard & 0.000 & 0.012 & 0.000 & 0.000 & 0.037 & 9.218 & 39.901 \\
\hline Indicator & $X_{8}$ & $X_{9}$ & $X_{10}$ & $X_{11}$ & $X_{12}$ & $X_{13}$ & $X_{14}$ \\
\hline$F$ - standard & 54.423 & 0.012 & 0.000 & 0.434 & 0.022 & 0.120 & 0.054 \\
\hline Indicator & $X_{15}$ & $X_{16}$ & $X_{17}$ & $X_{18}$ & $X_{19}$ & $X_{20}$ & $X_{21}$ \\
\hline$F$-standard & 0.007 & 0.059 & 0.026 & 0.063 & 0.730 & 10.953 & 0.001 \\
\hline Indicator & $X 22$ & $X 23$ & $X 24$ & $X 25$ & $\mathrm{X} 26$ & $X 27$ & $X 28$ \\
\hline$F$-standard & 0.000 & 6.659 & 0.007 & 34.022 & 0.000 & 1.945 & 0.001 \\
\hline Indicator & \multicolumn{2}{|c|}{$X_{29}$} & \multicolumn{2}{|c|}{$X_{30}$} & \multicolumn{3}{|c|}{$X_{31}$} \\
\hline$F$-standard & \multicolumn{2}{|c|}{0.000} & \multicolumn{2}{|c|}{0.094} & \multicolumn{3}{|c|}{0.000} \\
\hline
\end{tabular}

Source: compiled by the authors.

Table 3. Matrix of the pair coefficients of the correlation of insurance companies

\begin{tabular}{|l|l|l|l|l|l|l|l|l|}
\hline Indicator & $\mathrm{X}_{6}$ & $\mathrm{X}_{7}$ & $\mathrm{X}_{8}$ & $\mathrm{X}_{11}$ & $\mathrm{X}_{19}$ & $\mathrm{X}_{20}$ & $\mathrm{X}_{23}$ & $\mathrm{X}_{25}$ \\
\hline $\mathrm{X}_{6}$ & 1.000 & & & & & & & \\
\hline $\mathrm{X}_{7}$ & 0.995 & 1.000 & & & & & & \\
\hline $\mathrm{X}_{8}$ & 0.241 & 0.283 & 1.000 & & & & & \\
\hline $\mathrm{X}_{11}$ & -0.243 & -0.193 & 0.405 & 1.000 & & & & \\
\hline $\mathrm{X}_{19}$ & -0.086 & -0.034 & 0.504 & 0.828 & 1.000 & & & \\
\hline $\mathrm{X}_{20}$ & -0.030 & 0.025 & 0.675 & 0.782 & 0.951 & 1.000 & & \\
\hline $\mathrm{X}_{23}$ & -0.287 & -0.228 & 0.560 & 0.749 & 0.930 & 0.941 & 1.000 & \\
\hline $\mathrm{X}_{25}$ & 0.804 & 0.750 & -0.013 & -0.329 & -0.268 & -0.256 & -0.481 & 1.000 \\
\hline
\end{tabular}

Source: compiled by the authors.

Table 4. Average values of indicators of financially stable and liquidated insurance companies and the vector of their differences

\begin{tabular}{|l|c|c|c|c|}
\hline \multicolumn{1}{|c|}{ Indicator } & $X_{1}$ & $X_{2}$ & $X_{3}$ & $X_{4}$ \\
\hline Average for sustainable insurance companies & -0.08 & 0.77 & 1.78 & 1.10 \\
\hline Average for liquidated insurance companies & 0.04 & 0.08 & 0.18 & 0.83 \\
\hline The difference between the average values of 2 groups & -0.12 & 0.69 & 1.60 & 0.28 \\
\hline
\end{tabular}

Source: compiled by the authors

Having found an inverted matrix W-1 and multiplying its value and the vector of difference between the mean values of independent variables for two groups of insurance companies, we obtained a matrix of nonstandardized discriminant coefficients. Having defined the normalized coefficients and then standardizing them, we obtained the parameters of a discriminant model (Table 5). 
Table 5. Value of normalized coefficients of discriminant function

\begin{tabular}{|c|c|c|c|c|}
\hline \multicolumn{1}{|c|}{ Indicator } & $X_{1}$ & $X_{2}$ & $X_{3}$ & $X_{4}$ \\
\hline Normalized value in model & -0.211 & 1.112 & -0.126 & 0.019 \\
\hline
\end{tabular}

Source: compiled by the authors.

In accordance with the calculations made by us, the discriminant function of the financial condition of insurance companies, which was constructed, is of the following form :

$$
Z=-0.211 \times X_{1}+1.112 \times X_{2}-0.126 \times X_{3}+0.019 \times X_{4},
$$

where $X_{1}$ - net return on equity; $X_{2}$ - asset turnover ratio; $X_{3}$ - insurance risk index; $X_{4}$ - change in capital ratio.

To assign an insurance company to a financially stable or financially insolvent one, it is necessary to determine the critical value of the integral indicator - the line of division of groups. In the developed model, the critical value of the discriminant function is 0.37 . Thus, the scale of interpretation of the indicator $\mathrm{Z}$ is as follows:

$Z \leq 0,04$ - the financial condition of the insurance company is unsatisfactory - she is in a crisis she is facing bankruptcy;

$0,04<Z<0,33$

- unambiguous conclusions about the financial status of an insurance company can not be made, it is necessary to carry out an additional in-depth analysis of the financial position of the company unambiguous conclusions about the financial status of an insurance company can not be made, it is necessary to carry out an additional in-depth analysis of the financial position of the company;

$Z \geq 0,33$ - the financial condition of the insurance company is satisfactory.

It should be noted that in general we have identified 7 variants of the model, alternating the factors of the pairs that have a close connection, but the factors that we have chosen in the final version of the model provide the highest number of matches (for 6 out of 6 insurance companies the status of stable and for 3 out of 6 - the status of liquidated) (Table 6). Consequently, $75 \%$ of insurance companies confirmed their status.

At the final stage of work, we checked the adequacy of forecasts for the model received. After calculating the results, we obtained the following results: the average square error (MSE) is $9 \%$, with the MAE criterion, the average absolute error is $29 \%$, and Tayla's coefficient is 0.33 . Since the RMSE is $30 \%$, the forecast is satisfactory.

Table 6. Value of discriminatory function for insurance companies of Ukraine

\begin{tabular}{|l|c|c|}
\hline \multicolumn{1}{|c|}{ Insurance Company } & The value of the discriminant function & $\begin{array}{c}Z \leq 0.04 \text { or } Z \geq 0.33 . \\
\text { or } 0.04<Z<0.33 \\
\text { according to the scale of } \\
\text { interpretation }\end{array}$ \\
\hline PJSC NASK "ORANTA" & 0.530 & $Z \geq 0.33$ \\
\hline PJSC Insurance Company "Providna" & 0.743 & $Z \geq 0.33$ \\
\hline PJSC SG “TAS" & 0.674 & $Z \geq 0.33$ \\
\hline PJSC "UPSK" & 0.689 & $Z \geq 0.33$ \\
\hline PJSC USC "Knyazha" & 0.766 & $Z \geq 0.33$ \\
\hline PJSC Insurance Company "Unika" & 0.581 & $0.04<Z<0.33$ \\
\hline PJSC IC "Vector Invest" & 0.249 & $Z \leq 0.04$ \\
\hline PJSC IC "Vector Invest Life" & 0.017 & $Z \leq 0.04$ \\
\hline PJSC SC "Standard Re" & 0.015 & $Z \geq 0.33$ \\
\hline PJSC Insurance Company "Zlagoda" & 0.058 & $Z \leq 0.04$ \\
\hline PJSC SC “Atlanta" & 0.021 & $Z \geq 0.33$ \\
\hline PJSC USC "Garant-Life" & 0.069 & $Z$ \\
\hline
\end{tabular}

Source: compiled by the authors. 


\section{Conclusions}

In the insurance sector of Ukraine, during the 2014-2015 biennium, a wave of bankruptcies and denial of licenses of insurance companies was observed. This was caused by the following as factors of a microeconomic nature: violation of licensing conditions, violation of the legislation on regulating and supervising the activities of insurers, as well as macroeconomic factors - military aggression, devaluation of the national currency, distrust of the authorities and the financial sector, high level of corruption, low investment attractiveness and a significant debt burden. The emergence of crisis in the insurance sector violates the stability of the financial sector, which is the main task of financial supervision in the country. Improving the effectiveness of the financial oversight bodies requires timely assessment of the financial situation of insurance companies, crisis forecasting and early response to identifying risks and shocks. In turn, this requires expanding the tools of out-of-bounds financial supervision and improving the tools for forecasting the financial condition of insurance companies.

The research of the existing experience of discriminatory analysis to determine the financial state and forecasting bankruptcy has shown that it is most widely used for the needs of financial analysis of companies in the real sector. This is due to the relative simplicity of the discriminatory analysis and the rather high quality of predictive estimates. Also, foreign science and practice have developed discriminatory models for banking institutions and insurance companies. Given that the development of discriminatory models is based on the existing experience of both stable financial intermediaries and bankrupt brokers, the use of foreign models in Ukrainian realities is not entirely correct. In view of this, an important analytical task is to develop discriminatory models for determining the financial position of financial intermediaries in general and insurance companies in particular, taking into account the specifics of the financial sector and the insurance market of Ukraine.

The construction of a discriminant model for determining the financial status of insurance companies in Ukraine was carried out in the following stages: the selection of liquidated and stable insurance companies, the formation of an array of data for use in the process of constructing a model, selection and calculation of indicators, which will be used to assess the financial condition of the insurance company, check the significance of the factors, selected for the model with the help of a two-sample F-test for dispersions, evaluation of the relationship between the selected indicators (checking the presence of multicollinearity $\mathrm{m}$ and alternatives using the Farrar-Globe algorithm and by constructing a matrix of pair correlation coefficients), constructing a discriminant function equation, checking its adequacy and reliability, applying a discriminant model to predict the financial condition of insurance companies and checking its adequacy.

For the research 12 insurance companies of Ukraine, 6 of which have a stable financial status, the remaining 6 were liquidated were selected. Of the 31 financial indicators calculated for these companies based on their financial statements for 2015, eight indicators were retained in accordance with the obtained F-criterion values. To detect and eliminate the multicollinearity between the factors, the Farrar-Globard algorithm was applied and the matrix of the pair correlation coefficients was constructed. The calculations made it possible to substantiate that the following factors can be included in the discriminatory model of determining the financial position of Ukrainian insurance companies: net return on equity, asset turnover ratio, insurance risk index and capital change indicator.

In the process of application of scientific and methodical tools of discriminatory analysis, a discriminatory function of determining the financial status of insurance companies of Ukraine was determined, which is as follows: $Z=-0.211 \times X_{1}+1.112 \times X_{2}-0.126 \times X_{3}+0.019 \times X_{4}$. To determine the financial condition of an insurance company, a gradation of the values of a discriminant function was defined: if $Z \leq 0,04$, then the financial condition of the insurance company is unsatisfactory - it is in a crisis that it faces bankruptcy; if $0,04<Z<0,33$, then unambiguous conclusions about the financial status of an insurance company can not be made, it is necessary to conduct an additional in-depth analysis of the company's financial position; if $Z \geq 0,33$ - the financial condition of the insurance company is satisfactory.

Approbation of the developed discriminatory model for determining the financial condition of Ukrainian insurance companies for the insurance companies surveyed confirmed the status of all financially stable insurance companies and half of the bankruptcy insurance companies. The quality of the forecast, compiled using a discriminant function, is acceptable given the mean square error, the mean absolute error, the Tayl coefficient, and the mean square error. 


\section{References}

1. Anghelache, C., Armeanu, D. (2008). Application of Discriminant Analysis on Romanian Insurance Market. Theoretical and Applied Economics, 11 (528), 51-62.

2. Barr Richard, S., Thomas, S. (1996). Bank Failure Prediction Using DEA to Measure Management Quality, Southern Methodist University.

3. Beaver, W. H. (1966). Financial Rations and Predictions of Failure. Empirical Research in Accounting Selected Studies. Supplement to Journal of Accounting Research, 45-49.

4. Cherep, A. V., Komisarenko, O. A. (2013). Rozrobka modeli prohnozuvannia bankrutstva komertsiinykh bankiv Ukrainy na osnovi zarubizhnoho dosvidu [Development of a model for forecasting bankruptcy of commercial banks of Ukraine on the basis of foreign experience]. Financial and credit activity: problems of theory and practice, 1, 18-23.

5. Chesser, D. L. (1974). Predicting Loan Noncompliance. The Journal of Commercial Bank Lending, 56 (12), 28-38.

6. Conan, J., Holder, M. (1979). Variables explicatives de performance et controle de gestion dans les P.M.I., These d'Etat, CERG, Universite Paris Dauphine.

7. Erdogan, B. E. (2008). Bankruptcy of Turkish Commercial Banks Using Financial Ratios. Applied Mathematical Sciences, 60, 2973-2982.

8. Financial statements of insurance companies. Retrieved from: http://www.smida.gov.ua. Accessed 1 June 2017.

9. Fulmer, J. G. (1984). A Bankruptcy Classification Model For Small Firms. Journal of Commercial Bank Lending, 25-37.

10. Gilbert, L. R., Krishnagopal, M., Schwartz, K. B. (1990). Predicting Bankruptcy for Firms in Financial Distress. Journal of Business Finance \& Accounting, 161-171.

11. Halling, M., Hayden, E. (2008). Bank Failure Prediction: A Two-Step Survival Time Approach. IFC Bulletin, 28, 48-73.

12. Hanweck, G. A. (1977). Predicting Bank Failure. Research Papers in Banking and Financial Economics. Financial Studies Section, Division of Research and Statistics, Board of Governors of the Federal Reserve System.

13. Iankovets, T. M., Cherniuk, Yu. V. (2016). Porivniannia suchasnykh modelei diahnostyky ymovirnosti bankrutstva pidpryiemstva: zakordonnyi ta vitchyznianyi dosvid. Comparison of modern models for diagnosing the probability of bankruptcy of an enterprise: foreign and domestic experience. Economics. Investments: practice and experience, 20, 58-62.

14. Kaciak, E. (2000). Predicting bank failures in a newly emerging free-market economy. PerspectivesElectronic Journal of the American Association of Behavioral and Social Sciences, 105-117.

15. Martin, D. (1977). Early-warning of Bank Failure: A Logit Regression Approach. Journal of Banking and Finance, 1, 249-276.

16. Martinez, Z. D., Menendez, J. F., Vargas, J. S. (2004) See5 Algorithm versus Discriminant Analysis. An Application to the Prediction of Insolvency in Spanish Non-life Insurance Companies. Documentos de trabajo de la Facultad de Ciencias Económicas y Empresariales. Retrieved from: http://eprints.ucm.es/ 6836/1/0412.pdf.

17. Report of the National Commission that performs state regulation in the field of financial services markets. Retrieved from: https://nfp.gov.ua.

18. Springate, L.V. Gordon (1978). Predicting the Possibility of Failure in a Canadian Firm. Unpublished M.B.A. Research Project, Simon Fraser University.

19. Taffler, R. J., Tisshaw, H. (1977). Going, going, gone - four factors which predict. Accountancy, 50-54.

20. Tereshchenko, O. O. (2003). Dyskryminantna model intehralnoi otsinky finansovoho stanu pidpryiemstva Discriminant model of the integrated assessment of the financial condition of the enterprise. Ukraine economy, 8, 38-44. 